Journal of Research in Technical Careers

May 2020, Vol. 4, No. 1.

(C) Author(s)

\title{
Games in Agriculture, Food, and Natural Resources Education
}

\author{
Aaron J. McKim ${ }^{\mathrm{a}}$, Robert Bud McKendree ${ }^{\mathrm{a}}$, Catlin M. Pauley ${ }^{\mathrm{b}}$ \\ ${ }^{a}$ Michigan State University, ${ }^{b}$ Granville Jr./Sr. High School
}

\begin{abstract}
Educational games provide learners with team-based, experiential, and problem-centered learning opportunities. Therefore, educational games are recommended to encourage learner success in an increasingly complex and collaborative world. Research exploring interventions to increase teacher affinity toward games is needed to inform expansion of games within classrooms. The current study leveraged the input, environment, and outcomes model to analyze perceptions of games held by school-based agriculture, food, and natural resources (AFNR) educators before and after a professional development experience focused on educational games. Results indicate teachers held a favorable perception of games before engaging in the professional development. Engagement in the professional development was related to only minimal increases in the perceptions held by teachers regarding educational games. Importantly, individual items within the construct illuminate an expanded view of educational games and their utility within AFNR classrooms as a result of the professional development experience. Specifically, respondents saw educational games as being valuable to engage learners in new content, not just as a review tool. Findings suggest a professional development experience related to games may help expand teacher conceptualizations of educational game utility. Specific recommendations are included to expand teacher understanding and use of educational games.
\end{abstract}

Keywords: agriculture, food, and natural resources education; educational games; experiential learning; professional development; problem-centered learning

The increasing complexity and collaborative nature of our world, for which learners must be prepared, starkly contrasts with traditional, lecture-based learning environments (Teplitski \& McMahon, 2006). In lieu of traditional, expository approaches to education, scholars advocate for team-based, experiential, and problem-centered instruction (King, Dordel, Krzic, \& Simard, 2014). One teaching method that embodies these essential characteristics is educational games. Games are defined as "goal-directed competitive [activities], conducted within a framework of agreed upon rules" (Ranchhod, Gurau, Loukis, \& Trivedi, 2014, p. 76).

In addition to fostering transformed learning environments, games are increasingly familiar to learners, with three out of four households playing games on a regular basis (Bunch, Robinson, Edwards, \& Antonenko, 2014). Further, "digital natives" have shorter attention spans, prefer visual-based learning, have more social connections, and are more 


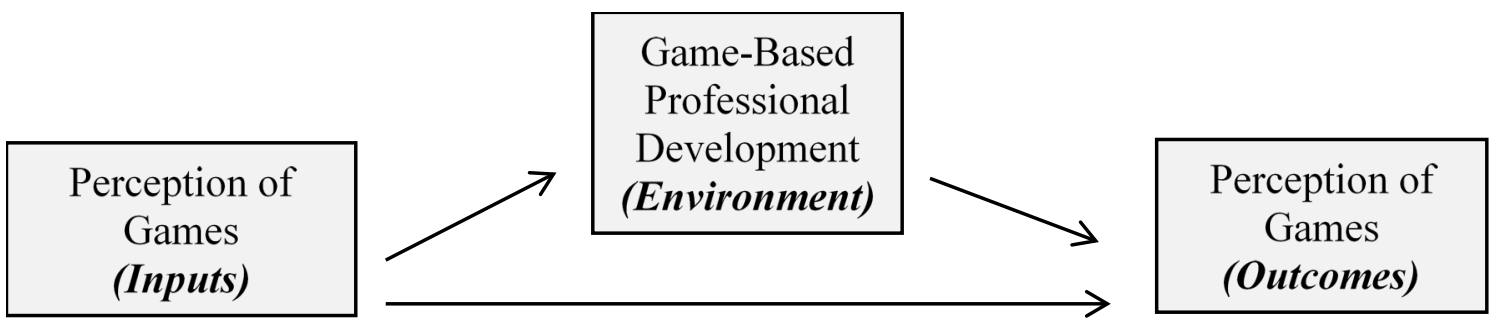

Figure 1. Astin's (1999) Inputs, Environment, and Outcomes Model operationalized for the current study.

comfortable playing games than previous generations (Deshpande \& Huang, 2009; King et al., 2014). Implementation of games, therefore, better attends to the characteristics of today's learners (King et al., 2014). Empirical evidence supports this, with research indicating educational games generate novel experiences for students, build conceptual understanding, help students develop interpersonal skills, and attend to the affective domain of learning (Cohen, 2011; Fox \& Loope, 2007; Hague, 2011; Jin, Bierma, \& Yang, 2016).

While existing literature showcases both the growing relevance and potential value of games, research within agriculture, food, and natural resources (AFNR) education has not adequately explored this educational approach (Bunch et al., 2014; Jin et al., 2016; King et al., 2014). Given the novelty of educational game-based research within AFNR education, the current study serves as a foundational investigation of secondary school AFNR teachers' perceptions of games. The knowledge gained through this investigation will provide useful insights regarding the value and utility perceived by AFNR educators concerning the inclusion of games within secondary school AFNR curriculum.

\section{Theoretical Framework}

The theoretical framework for this study is the input, environment, and outcomes (IEO) model (Figure 1), initially used in postsecondary education research (Astin, 1999). This model illustrates how individuals have measurable attributes (i.e., inputs) as they engage in an experience. Additionally, the model suggests experiences catalyze change among individuals, measured as outcomes of the experience. For example, individuals walk into learning experiences with preexisting knowledge and attitudes about the topic (i.e., inputs) and, because of the experience, their knowledge and attitudes change about the topic (i.e., outcomes). In the current analysis, we operationalized the IEO model by evaluating perceptions of games (i.e., inputs) before a professional development session (i.e., experience) and then compared those perceptions to perceptions after the professional development to better understand participant outcomes. 


\section{Purpose and Objectives}

The purpose of this study is to analyze the perceptions of school-based AFNR educators regarding games as well as to evaluate their perceptions before and after a professional development experience. This purpose was achieved via the following research objectives: (a) evaluate AFNR teacher perceptions of games and (b) compare AFNR teacher perceptions of games before and after engagement in a professional development session focused on games.

\section{Methods}

This study utilized a survey research design (Leedy \& Ormrod, 2013). Survey research was selected because it provided an opportunity to quantitatively understand the perceptions of teachers regarding educational games. Further, this survey design allowed for consistent comparisons of teacher perceptions regarding educational games before and after participation in a professional development focused on educational games. The quantitative survey data utilized were derived from a larger, multi-methodological research project exploring game usage within AFNR education. All research methods were approved by the Institutional Review Board (IRB) at Michigan State University.

Population, Sample, and Data Collection. The population included all Michigan school-based AFNR educators who participated in a professional development session titled "Game On School-Based Agricultural Education: Using Interactive Games to Enhance Student Learning" offered during the Michigan Fall Professional Development Institute. Paper surveys and writing utensils were distributed immediately before and immediately after the 90-minute professional development session to all participants $(N=$ 63), which totaled $60 \%$ of attendees at the Michigan Fall Professional Development Institute. Fifty $(\mathrm{n}=50)$ participants submitted complete pre and post surveys, yielding a $79.37 \%$ usable response rate. Due to the purposive sampling procedures, no attempt is made to infer findings beyond respondents.

Description of Professional Development. The professional development session, facilitated by the authors of this research, included a 15-minute introduction to games and justification for using games in educational settings. Following the introduction, participants were led in playing four games titled Shifting Systems; The Coopetition Game; Seek, Solve, Unscramble; and The Photosynthesis Game (Table 1). After playing each game, facilitators led a debrief in which participants discussed their experiences playing the game, potential learning outcomes achievable via the game, and methods for adapting the game to meet different learning objectives.

Instrumentation. The Perceptions of Educational Games (PEG) construct, used to evaluate teacher perceptions of games, was adapted from Kenny and McDaniel (2011), who explored teacher perceptions of video games within classrooms. The wording of the PEG construct was changed from video games to educational games, resulting in a more 
Table 1. Description of Professional Development Games

\begin{tabular}{|c|c|c|}
\hline Title & Description & Utility \\
\hline Shifting Systems & $\begin{array}{l}\text { Each participant is asked to secretly select two other } \\
\text { participants in the room. Then, participants continually } \\
\text { move to form an equilateral triangle with the two } \\
\text { individuals they have selected, who may or may not have } \\
\text { selected them. The size of the group will influence how } \\
\text { long it takes for the system to stop shifting. As an } \\
\text { extension, after individuals have stopped moving, the } \\
\text { facilitator can selectively move individuals and have the } \\
\text { system re-organize accordingly. }\end{array}$ & $\begin{array}{l}\text { Showcases how systems } \\
\text { are continually evolving } \\
\text { and how shifts among } \\
\text { actors or agents within a } \\
\text { system cause the whole } \\
\text { system to adjust. }\end{array}$ \\
\hline $\begin{array}{l}\text { Coopetition } \\
\text { Game }\end{array}$ & $\begin{array}{l}\text { Participants are lined up and given an index card with } \\
\text { option A on one side and option B on the other side. } \\
\text { After learning how points are allocated, and at the same } \\
\text { time, participants show their selected option by holding } \\
\text { up their card to show the facilitator. If none of the } \\
\text { participants hold up B, each member of the group is } \\
\text { awarded five points. If less than } 10 \% \text { of participants hold } \\
\text { up B, the participants holding up B receive ten points and } \\
\text { the participants holding up A receive zero points. If more } \\
\text { than } 10 \% \text { of participants hold up B, none of the students } \\
\text { receive any points. }\end{array}$ & $\begin{array}{l}\text { Illustrates how } \\
\text { individual actions can } \\
\text { be destructive to overall } \\
\text { group success, a topic } \\
\text { useful for introducing } \\
\text { challenges to leadership } \\
\text { and sustainability } \\
\text { efforts among other } \\
\text { topics. }\end{array}$ \\
\hline $\begin{array}{l}\text { Seek, Solve, } \\
\text { Unscramble }\end{array}$ & $\begin{array}{l}\text { Participants are grouped into teams of three to four and } \\
\text { tasked with answering multiple-choice questions placed } \\
\text { around the room. The correct answers to the questions } \\
\text { provide a collection of letters students must unscramble } \\
\text { to form a word or short phrase corresponding to the } \\
\text { content. }\end{array}$ & $\begin{array}{l}\text { Opportunity for students } \\
\text { to review key concepts. } \\
\text { Can also be used as a } \\
\text { preassessment of } \\
\text { knowledge on a topic. }\end{array}$ \\
\hline $\begin{array}{l}\text { Photosynthesis } \\
\text { Game }\end{array}$ & $\begin{array}{l}\text { Participants are split into two teams and each team is } \\
\text { given an envelope of potential reactants for the chemical } \\
\text { equation of photosynthesis. One-by-one, participants find } \\
\text { the correct reactants and race to place them in an } \\
\text { envelope on the other side of the room, decorated as a } \\
\text { leaf. Once the reactants are correctly added to the leaf, } \\
\text { the remaining team members race to the leaf where } \\
\text { potential products are placed. One-by-one, participants } \\
\text { find the correct products and race to bring them back to } \\
\text { the team's starting position. }\end{array}$ & $\begin{array}{l}\text { While specific to } \\
\text { photosynthesis, this } \\
\text { activity is replicable for } \\
\text { other content areas in } \\
\text { which identifying } \\
\text { specific inputs and } \\
\text { outputs of a system, } \\
\text { equation, or organism is } \\
\text { important. }\end{array}$ \\
\hline
\end{tabular}

applicable data collection instrument given the focus of the study. The PEG construct included 10 questions, included in Table 2. Responses were recorded from 1 (strongly disagree) to 5 (strongly agree). Face and content validity were evaluated by a panel of three experts in educational research. Reliability was evaluated post hoc, with the PEG construct being reliable (Fraenkel \& Wallen, 2000; Nunnally \& Bernstein, 1994) for both 
Table 2. AFNR Teacher Perceptions of Games

\begin{tabular}{|c|c|c|c|c|c|}
\hline \multirow{2}{*}{$\begin{array}{l}\text { Item } \\
\text { Number }\end{array}$} & \multirow[b]{2}{*}{ Construct Items } & \multicolumn{2}{|c|}{$\begin{array}{c}\text { Before Professional } \\
\text { Development }\end{array}$} & \multicolumn{2}{|c|}{$\begin{array}{l}\text { After Professional } \\
\text { Development }\end{array}$} \\
\hline & & $M$ & $S D$ & $M$ & $S D$ \\
\hline 1 & $\begin{array}{l}\text { Educational games can be used to teach } \\
\text { things in the classroom. }\end{array}$ & 4.38 & 0.95 & 4.59 & 0.61 \\
\hline 2 & $\begin{array}{l}\text { I prefer to utilize games which have a } \\
\text { strong educational meaning. }\end{array}$ & 4.14 & 0.79 & 4.32 & 0.59 \\
\hline 3 & $\begin{array}{l}\text { Educational games are too complex to } \\
\text { learn. }\end{array}$ & 4.12 & 0.73 & 4.00 & 0.82 \\
\hline 4 & $\begin{array}{l}\text { Educational games are too time- } \\
\text { consuming to utilize in the classroom. }\end{array}$ & 4.00 & 0.80 & 4.08 & 0.64 \\
\hline 5 & $\begin{array}{l}\text { I feel comfortable utilizing educational } \\
\text { games. }\end{array}$ & 3.98 & 0.74 & 4.26 & 0.53 \\
\hline 6 & $\begin{array}{l}\text { The act of facilitating educational games } \\
\text { is intimidating to me. }\end{array}$ & 3.92 & 0.97 & 4.02 & 0.83 \\
\hline 7 & $\begin{array}{l}\text { Educational games create too much } \\
\text { conflict in a classroom. }\end{array}$ & 3.90 & 0.93 & 3.84 & 0.89 \\
\hline 8 & $\begin{array}{l}\text { The rules of educational games make } \\
\text { them too difficult to use. }\end{array}$ & 3.84 & 0.66 & 3.96 & 0.67 \\
\hline 9 & $\begin{array}{l}\text { I utilize educational games on a regular } \\
\text { basis. }\end{array}$ & 3.74 & 1.08 & 3.56 & 1.03 \\
\hline 10 & $\begin{array}{l}\text { I would rather teach in other ways than } \\
\text { use educational games. }\end{array}$ & 3.68 & 0.82 & 3.88 & 0.82 \\
\hline & Total & 3.96 & 0.52 & 4.05 & 0.47 \\
\hline
\end{tabular}

Note. Items measured from 1 (strongly disagree) to 5 (strongly agree). Items, 3, 4, 6, 7, 8, and 10 are reverse coded and are reported using reversed means.

the pre- $($ Cronbach's alpha $=.82)$ and post-professional-development distribution of the survey (Cronbach's alpha $=.81)$.

Data Analysis. Surveys completed before and after the professional development experience were gathered and matched for each respondent. Then, data were input into a statistical processing software program (i.e., SPSS) for analysis. Means and standard deviations were calculated for each of the 10 PEG construct items for both waves of data collection (i.e., before and after the professional development experience). In addition, a summated mean and standard deviation was calculated by averaging responses across the 
Journal of Research in Technical Careers

10 PEG construct items for both points of data collection. In total, data analysis yielded a clear comparison of perceptions of educational games before and after participation in the professional development.

\section{Findings}

Research objective one focuses on teacher perceptions of educational games (Table 2 ). Before engaging in the professional development, teachers reported a generally positive perception of games $(M=3.96 ; S D=0.52)$. In the pre-survey results, respondents agreed most with the statement, "educational games can be used to teach things in the classroom" $(M=4.38 ; S D=0.95)$. Alternatively, the item "I would rather teach in other ways than use educational games" received the lowest average response $(M=3.68 ; S D=0.82)$.

Research objective two shifts the focus to comparing perceptions of educational games before and after participation in the professional development. After engaging in the professional development, teachers again reported generally positive perceptions of games $(M=4.05 ; S D=0.47)$. For the post survey, the most favorably perceived item was, again, "educational games can be used to teach things in the classroom" $(M=4.59 ; S D=0.61)$ while "I utilize educational games on a regular basis" was the lowest rated item within the construct $(M=3.56 ; S D=1.03)$.

Overall, when comparing perceptions of educational games before and after the professional development experience, perceptions increased negligibly $(\Delta M=0.09)$. Looking within the construct items, more favorable perceptions of educational games after the professional development were seen in seven of the ten construct items (i.e., items 1, $2,4,5,6,8$, and 10). The largest increase was seen for the item "I prefer to utilize games which have a strong educational meaning" $(\Delta M=0.28)$. Among those items in which a decrease was seen, the largest decrease was observed for the item "I utilize educational games on a regular basis" $(\Delta M=-0.18)$.

\section{Conclusions and Discussion}

The current study provides a foundational understanding of teacher perceptions regarding educational games and how perceptions of educational games change after participation in a professional development. Before participating in the professional development, teachers held relatively positive perceptions of educational games. Importantly, however, the teachers who responded to the survey self-selected into a professional development session focused on using games in school-based AFNR education; therefore, it is likely their perceptions were more favorable regarding educational games than those teachers who did not participate in the professional development. Nonetheless, a positive perception of games among teachers before the professional development is encouraging given the educational potential of games (Cohen, 2011; Fox \& Loope, 2007; Hague, 2011; Jin et al., 2016) and alignment between gamebased educational approaches and the increasingly complex and collaborative world (Teplitski \& McMahon, 2006). 
Only negligible differences were observed in teacher perceptions of educational games after participating in the professional development. Overall, this suggests that a 90minute professional development on games, as the experience, may not suffice to cause immediate, substantial change in teacher outcomes (Astin, 1999). Alternatively, teachers may withhold changing perceptions of educational games until they receive confirmation of the value educational games possess by utilizing them with their students, a hypothesis supported by the Model of Teacher Change (Guskey, 2002) and the Diffusion of Innovations Theory (Rogers, 2003). This suggests changing the perception of teachers regarding educational games requires teachers have time to actually use games within their classroom, confirming their ability to implement educational games as an instructional strategy and confirming students are engaged and learning when playing educational games.

Although only negligible differences were observed in perceptions of educational games, closer inspection of the individual items found within the PEG construct may illuminate valuable gains among participants. In particular, a decline in the item "I utilize educational games on a regular basis" may belie a more rigorous personal definition of what educational games are, shifting perceptions of educational games beyond the common, competitive question answering review games (e.g., review Jeopardy). Teachers who perceived educational games as experiences that can be more complex and collaborative than previously envisioned were a potential product of the professional development. This idea is supported by the two largest increases in perceptions being for the items "I prefer to utilize games which have a strong educational meaning" and "educational games can be used to teach things in the classroom," suggesting that teachers, after the professional development, saw educational games as useful in the formative stages of learning as opposed to only the summative stages.

This research suggests outcomes of a professional development on educational games may be multi-dimensional, including (a) perceiving more games in educational settings as positive and (b) perceiving games with more educational meaning as positive. In this case, teachers who do not perceive educational games as valuable when they start the professional development may experience more growth in the first dimension, leaving the professional development with a desire to use educational games in their classroom. However, for teachers who think highly of educational games before engaging in the professional development, similar to the respondents in the current study, we would only expect increases in the second dimension, with these teachers leaving committed to transforming the games they use in the classroom to be more complex, rigorous, and educational valuable.

\section{Recommendations}

Four recommendations have emerged from this research on teacher perceptions of educational games in AFNR education. First, to leverage the favorable views toward games held by teachers, those in curriculum development and instructional methods elements of teacher education are encouraged to include educational games as a teaching methodology. Second, those looking to increase the perceptions of teachers regarding educational games 
are encouraged to consider sustained professional development opportunities with chances for participants to "try out" games for confirmation of their educational efficacy. Further, longitudinal research is needed to assess teachers throughout their journey of implementing educational games in order to evaluate the evolution of teacher perceptions as they try out games within their own classrooms. Third, as interventions are initiated to increase game utilization in AFNR education, facilitators are encouraged to select games that represent the broad utility of educational games for AFNR educators. For example, games that can be used to introduce, teach, extend, and/or evaluate content learning or skill development are recommended. Fourth, a factor analysis of the PEG construct is recommended to identify the potential of two factors, one factor associated with increasing the number of games within educational settings and another factor associated with increasing the quality of games within educational settings.

Educational games provide a viable method to develop learners who can work collaboratively to solve problems (Ranchhod et al., 2014). The lack of research on educational games in AFNR education leaves participants throughout AFNR education without the knowledge or resources needed to make informed decisions to support expanded use of educational games. The current study provides a foundation of knowledge from which to build additional research and practice that will increase the quality of instruction in AFNR education through educational games.

\section{References}

Astin, A. W. (1999). Student involvement: A developmental theory for higher education. Journal of College Student Development, 40(5), 518-529.

Bunch, J. C., Robinson, J. S., Edwards, M. C., \& Antonenko, P. D. (2014). How a serious digital game affected students' animal science and mathematics competence in agricultural education. Journal of Agricultural Education, 55(3), 57-71. https://doi.org/10.5032/jae.2014.03057

Cohen, A. M. (2011). The gamification of education. Futurist, 45, 16-17.

Deshpande, A. A., and S. H. Huang. 2009. Simulation games in engineering education: A stateof-the-art review. Computer Applications in Engineering Education, 19(3): 399-410. https://doi.org/10.1002/cae.20323

Fox, A. M., \& Loope, L. L. (2007). Globalization and invasive species issues in Hawaii: Roleplaying some local perspectives. Journal of Natural Resources \& Life Sciences Education, 36, 147-157. https://doi.org/10.2134/jnrlse2007.361147x

Fraenkel, J. R., \& Wallen, N. E. (2000). How to design and evaluate research in education. New York, NY: McGraw-Hill.

Guskey, T. R. (2002). Professional development and teacher change. Teachers and Teaching, 8(3), 381-391. https://doi.org/10.1080/135406002100000512

Hague, S. S. (2011). Fantasy seed company: A role playing game for plant breeding courses. Journal of Natural Resources \& Life Sciences Education, 40, 168-171.

Jin, G., Bierma, T., \& Yang, L. (2016). Cap-and-trade: Understanding and teaching a marketbased approach to natural resource allocation. Journal of Natural Sciences Education, 45(1), 1-11. https://doi.org/10.4195/nse2015.0030

Kenny, R. F., \& McDaniel, R. (2011). The role teachers' expectations and value assessments of video games play in their adopting and integrating them into their classrooms. British 
Journal of Educational Technology, 42(2), 197-213. https://doi.org/10.1111/j.14678535.2009.01007.x

King, C., Dordel, J., Krzic, M., \& Simard, S. W. (2014). Integrating a mobile-based gaming application into a postsecondary forest ecology course. Natural Sciences Education 43(1), 117-125. https://doi.org/10.4195/nse2014.02.0004

Leedy, P. D., \& Ormrod, J. E. (2013). Practical research: Planning and design (10th ed.). Cranbury, NJ: Pearson Education, Inc.

Nunnally, J. C., \& Bernstein, I. H. (1994). Psychometric theory (3rd ed.). New York, NY: McGraw-Hill.

Ranchhod, A., Gurau, C., Loukis, E., \& Trivedi, R. (2014). Evaluating the educational effectiveness of simulation games: A value generation model. Information Sciences, 264, 75-90. https://doi.org/10.1016/j.ins.2013.09.008

Rogers, E. M. (2003). Diffusion of innovations (5th ed.). New York, NY: The Free Press.

Teplitski, M., \& McMahon, M. J., (2006). Problem-based learning and creative instructional approaches for laboratory exercises in introductory crop science. Journal of Natural Resources \& Life Sciences Education, 35(1), 209-216.

https://doi.org/10.2134/jnrlse2006.020 